\title{
Perlindungan Hak-Hak Masyarakat Adat Menurut Hukum Internasional
}

\author{
Ahmad Syofyan
}

Dosen Bagian Hukum Internasional Fakultas Hukum Universitas Lampung

\begin{abstract}
Abstrak
Hak masyarakat adat telah diatur dalam beberapa perjanjian internasional. Masyarakat adat dalam hukum internasional merupakan bagian dari hak asasi manusia baik itu secara individu maupun kelompok (kolektif). Prinsip dasar hukum internasional dan hukum hak asasi manusia telah diterima masuk kedalam hukum nasional dan pada tataran implementatif peraturan hukum nasional untuk memperhatikan perlindungan hak-hak masyarakat adat dapat terjamin sesuai dengan semangat konstitusi dan hak asasi manusia di Indonesia. Metode penelitian yang digunakan dalam penelitian ini adalah pendekatan yuridis normatif dengan spesifikasi penelitian deskriptif analitis. Pencarian data berupa bahan hukum primer dan sekunder serta tersier, data-data yang dikumpulkan bersumberkan pada bahan pustaka, kemudian dianalisis dengan menggunakan metode yuridis kualitatif. Penelitian ini menitik beratkan pada kajian teori hak asasi manusia baik secara individu maupun kolektif sebagai bentuk perlindungan hak asasi manusia sesuai dengan kaidah hukum internasional dan hukum nasional. Dalam pengaturan hukum internasional dan nasional, khususnya hukum nasional yang berhubungan dengan perlindungan hak-hak masyarakat adat. Dalam hal penelitian ini juga membahas bentuk-bentuk perlindungan terhadap hak-hak masyarakat adat baik menurut ketentuan-ketentuan hukum internasional dan peraturan perundang-undangan di Indonesia.
\end{abstract}

\section{Kata kunci : Perindungan, Hak Masyarakat adat dan Hukum Internasional}

\section{A. Latar Belakang}

Hak dasar adalah hak setiap orang untuk dapat menikmati kehidupan yang bermartabat dan hak yang diakui dalam peraturan perundang-undangan. Secara umum hak dasar ini antara lain meliputi terpenuhinya kebutuhan pangan, kesehatan, pendidikan, pekerjaan, perumahan, air bersih, pertanahan, sumberdaya alam dan lingkungan hidup, rasa aman dari perlakuan atau ancaman tindak kekerasan, dan hak untuk berpartisipasi dalam kehidupan sosial-politik, baik bagi perempuan maupun laki-laki. Hak dasar tidak berdiri sendiri, tetapi saling mempengaruhi satu sama lain. Tidak terpenuhinya satu hak dapat mempengaruhi pemenuhan hak lainnya. Hak dasar sebagai hak asasi pada hakekatnya melekat pada setiap orang dan tidak dapat diingkari oleh siapapun. Negara dan pemerintah bertanggung jawab untuk memberikan jaminan perlindungan dan pemenuhannya secara berkeadilan bagi setiap warga negara. Demikian pula, masyarakat dan setiap orang memiliki tanggung jawab untuk menghormati hak-hak warganya dan orang lain.

Hak masyarakat adat ${ }^{1}$ telah banyak diatur dalam hukum

1 Penggunaan istilah dalam penelitian ini mempunyai istilah yang sama atas penyebutan: indigenous peoples, masyarakat asli, penduduk asli dan masyarakat pribumi. 
internasional yaitu dalam beberapa perjanjian internasional. ${ }^{2}$ Hak masyarakat adat mempunyai standarisasi dalam hukum internasional terhadap pemenuhan hak asasi manusia baik itu secara individu maupun kelompok (kolektif). Prinsip dasar hukum internasional dan hukum hak asasi manusia telah diterima masuk kedalam hukum nasional dan pada tataran implementatif pengembangan kebijakan untuk memperhatikan pemenuhan hak-hak masyarakat adat dapat terjamin sesuai dengan semangat konstitusi dan hak asasi manusia.

Karakteristik umum masyarakat adat terletak pada hubungan kewilayahan (territory) mereka. Wilayah memberikan identifikasi sosial, spiritual dan budaya yang khusus bagi komunitas masyarakat adat serta hal itu membuat ketergantungan secara ekonomi terhadap tanah leluhur mereka. ${ }^{3}$ Masyarakat adat merupakan pemilik tradisional dari sejumlah besar persentase hutan dunia yang tersisa. Negara-negara memiliki kewajiban untuk mengakui, mengamankan dan melindungi hak milik masyarakat adat dan masyarakat tradisional, inter alia, melalui demarkasi, delimitasi dan pemberian sertifikat, yang dilakukan sesuai dengan norma-norma, nilai-

Seterusnya digunakan istilah masyarakat adat.

${ }^{2}$ Perjanjian internasional yang menyangkut hak masyarakat ada bersumber dari, yaitu: Universal Declaration of Human Rights (UDHR), International Covenan on Civil and Political Rights ICCPR), International Covenan on Economics, Sosial and Cultural Rights (ICESCR), ILO Convention No. 169 1989, United Nations Declaration on the Rights of Indegenous Peoples 2007.

3 Jayantha Perera, Land and Cultural Survival (The Communal Land Rights of Indigenous Peoples in Asia), ADB, 2009. Hlm. 15. nilai dan kebiasaan-kebiasaan masyarakat adat yang bersangkutan, dan harus mengadopsi atau mengamandemen kedalam hukum nasional mereka untuk tujuan tersebut jika perlu. ${ }^{4}$

Konstitusi-konstitusi modern di dunia, ditandai, salah satunya oleh penegasan atau pengaturan jaminan perlindungan hak-hak asasi manusia. Konstitusi-konstitusi yang mengadopsi prinsip-prinsip hak-hak asasi manusia, setidaknya telah mendorong pada suatu idealitas sistem politik (ketatanegaraan) yang bertanggung jawab pada rakyatnya, karena menegaskannya dalam hukum dasar atau tertinggi di suatu negara. Di sinilah sesungguhnya konteks relasi negara-rakyat diuji, tidak hanya dalam bentuknya yang termaterialkan dalam konstitusi sebuah negara, tetapi bagaimana negara mengimplementasikan tanggung jawabnya atas penghormatan, perlindungan, dan pemenuhan hakhak asasi manusia. ${ }^{5}$

Pengaturan hak asasi manusia telah banyak tercantum baik itu dalam hukum internasional maupun hukum nasional. Namun pada prakteknya seringkali terjadi pengabaian terhadap hak-hak masyarakat adat. Sehingga diperlukan pemahaman bagi pemangku kebijakan akan pengakuan serta pemenuhan perlindungan hak-hak

${ }^{4}$ Hak-Hak Masyarakat adat dan Pengurangan Emisi dari Pengurangan Deforestasi dan Degradasi Hutan: Perkara Masyarakat Saramaka melawan Suriname, Forest Peoples Programme, 2009. Hlm. 5. Lihat dalam http://www.forestpeoples.org/.../surinamesar amakaandreddjudgmentmar09ind.pdf, diakses pada tanggal 2 Pebruari 2011.

5 R. Herlambang Perdana Wiratraman, Konstitusionalisme \& Hak-Hak Asasi Manusia (Konsepsi Tanggung Jawab Negara Dalam Sistem Ketatanegaraan Indonesia), Jurnal Ilmu Hukum Yuridika Vol. 20, No. I, Januari 2005. Hlm. 2. 
masyarakat adat. Maka atas dasar pemikiran di atas maka peneliti hendak mengkaji dan perlu dilakukan penelitian dengan judul "Perlindungan Hak-Hak Masyarakat Adat Menurut Hukum Internasional dan Implementasinya di Indonesia."

Dari uraian latar belakang di atas, maka diidentifikasi beberapa permasalahan yang akan dikaji dalam penelitian ini adalah Bagaimana pengaturan hukum internasional terhadap perlindungan hak-hak masyarakat adat?

\section{B. Pembahasan}

Instrumen hak asasi manusia internasional yang ada saat ini diawali dengan akhir Perang Dunia II melalui pembentukan organisasi Internasional Perserikatan BangsaBangsa (PBB) pada tahun 1945 dan kerja dari Komisi Hak Asasi Manusia PBB (yang adalah suatu komisi fungsional di bawah Dewan Ekonomi dan Sosial PBB) untuk merumuskan tabulasi hak dan kebebasan dasar manusia yang dapat diterima secara universal.

Perkembangan selanjutnya hak asasi manusia bukan hanya memuat hak-hak individu melainkan hak-hak kolektif dan sebagai hak dasar dan nilai-nilai standar yang berlaku secara umum dan diakui oleh bangsa-bangsa yang beradab. Hak kolektif sebagai hak bersama yang dimiliki oleh entitas baik itu sebuah bangsa, kaum minoritas dan masyarakat adat. Hak-hak kolektif telah banyak tercantum kedalam perjanjian internasional mengenai penghormatan, pemenuhan dan perlindungan hak-hak mereka, baik itu secara partial maupun secara menyeluruh.

Perlindungan masyarakat adat dapat dilihat melalui berbagai kerangka normatif dan standar internasional yang mengatur hak-hak masyarakat adat. Sistem dan mekanisme internasional serta implementasi hak-hak masyarakat adat di Indonesia, termasuk badanbadan internasional yang terkait kerangka normatif kewajiban negara menurut sistem dan standar internasional dalam pemenuhan serta perlindungan hak-hak masyarakat adat melalui sumber-sumber acuan normatif kewajiban negara berdasarkan peraturan perundangundangan yang berlaku. Selanjutnya pembahasan ini menitikberatkan pada pengaturan hukum internasional terhadap perlindungan masyarakat adat dan implementasi pemenuhan perlindungan hak masyarakat adat di Indonesia.

\section{A. Pengaturan Internasional Perlindungan Masyarakat Adat \\ Hukum Terhadap Hak-Hak \\ Pada awalnya tanggungjawab} Komisi Hak Asasi Manusia meliputi tiga elemen, yaitu suatu pernyataan hak dan kebebasan, suatu daftar hak dan kebebasan yang mengikat secara hukum, dan yang terakhir suatu mekanisme untuk membuat hak-hak tersebut dapat ditegakkan sehingga memberi manfaat lansung bagi seluruh umat manusia. Ini semua akan menjadi instrumen pengaturan hukum internasional mengenai hak asasi manusia, yang merupakan suatu cetak biru konstitusional untuk tata dunia baru yang menentukan hak dan kebebasan yang disepakati dan dapat ditegakkan secara universal.

Sistem hukum hak asasi manusia internasional memberikan pengakuan hak masyarakat adat sebagai hak asasi manusia berakar pada Deklarasi Umum Hak Asasi Manusia yang muncul pada tahun 1947 dan disahkan oleh Majelis Umum Perserikatan Bangsa-Bangsa pada 10 Desember 1948. Deklarasi ini (selanjutkan akan disebut sebagai DUHAM), merupakan awal kodifikasi tentang standar pengakuan hak manusia yang di dalamnya termasuk 
hak masyarakat adat yang dimiliki melalui individu dan selanjutnya dapat diakui sebagai hak kolektif. Deklarasi ini diakui sebagai standar umum bagi semua masyarakat dan semua bangsa untuk berjuang bagi kemajuan martabat manusia.

$\begin{array}{ll} & \text { Pada umumnya yang menjadi } \\ \text { rujukan sebagai instrumen }\end{array}$ internasional HAM yang berkaitan dengan hak masyarakat adalah sejumlah dokumen hukum paling penting dalam lingkup PBB, yaitu:

a. Deklarasi Universal Hak Asasi Manusia 1948 (Universal Declaration of Human RightsUDHR) 1948.

b. Kovenan Internasional HakHak Ekonomi, Sosial Dan Budaya 1966 (International Covenant on Economic, Social and Cultural Rights 1966).

c. Kovenan Internasional HakHak Sipil dan Politik 1966 (International Covenant on Civil and Political Rights 1966).

d. Konvensi Internasional Penghapusan Segala Bentuk Diskriminasi Rasial 1965 (International Convention on the Elimination of All Forms of Racial Discrimination 1965).

e. Konvensi

Tentang Keanekaragaman Hayati 1992 (Convention On Biological Diversity 1992).

f. Konvensi ILO No. 107 Tahun 1957 tentang Perlindungan dan Integrasi dari Penduduk Pribumi, Masyarakat Adat dan Masyarakat Semi-adat di Negara-negara Merdeka (Convention No.107 concerning Protection and Integration of Indigenous and other Tribal and Semi-Tribal Population in Independent Countries).

g. Konvensi ILO No. 169 Tahun 1989 mengenai Bangsa
Pribumi dan Masyarakat Adat

di Negara-negara Merdeka

(Convention No. 169

concerning Indigenous and

Tribal Peoples in Independent

Countries).

h. Deklarasi Perserikatan

Bangsa-Bangsa (PBB)

Tentang Hak-Hak Masyarakat Adat 2007 (United Nations Declaration on the Rights of Indigenous Peoples 2007).

Deklarasi Universal Hak Asasi Manusia (DUHAM) adalah elemen pertama dari Peraturan PerundangUndangan Hak, yakni suatu hak dan kebebasan fundamental internasional. Kovenan-kovenan internasional menetapkan hak yang mengikat secara hukum dan Protokol Tambahan pada Kovenan Internasional tentang Hak Sipil dan Politik serta kedua komite yang memantau penerapan setiap Kovenan menyediakan mekanisme bagi penegakan hak-hak tersebut.

DUHAM membagi HAM beberapa jenis yaitu: 1 . hak personal (hak jaminan kebutuhan pribadi); 2. hak legal (hak jaminan perlindungan hukum); 3. hak sipil dan politik; 4. hak subsistensi (hak jaminan adanya sumber daya untuk menunjang kehidupan); 5. hak ekonomi, sosial dan budaya.

Hak dan kebebasan yang tercantum dalam DUHAM mencakup sekumpulan hak yang lengkap baik itu hak sipil, politik, budaya, ekonomi, dan sosial tiap individu maupun beberapa hak kolektif. Hubungan dengan kewajiban juga dinyatakan dalam Pasal 29 (1): "Setiap orang mempunyai kewajiban terhadap masyarakat tempat satu-satunya di mana dia dapat mengembangkan kepribadiannya dengan bebas dan penuh". Instrumen-instrumen yang dikeluarkan setelah DUHAM tidak mencakup penjabaran tentang kewajiban seperti itu. Selanjutnya Pasal 29 (2) menyatakan bahwa 
"Dalam menjalankan hak-hak dan kebebasan-kebebasannya, setiap orang harus tunduk hanya pada pembatasan-pembatasan yang ditetapkan oleh undang-undang yang tujuannya semata-mata untuk menjamin pengakuan serta penghormatan yang tepat terhadap hak-hak dan kebebasan-kebebasan orang lain, dan untuk memenuhi syarat-syarat yang adil dalam hal kesusilaan, ketertiban dan kesejahteraan umum dalam suatu masyarakat yang demokratis." Sedangkan Pasal (3) menyatakan bahwa "Hak-hak dan kebebasankebebasan ini dengan jalan bagaimana pun sekali-kali tidak boleh dilaksanakan bertentangan dengan tujuan dan prinsip-prinsip Perserikatan Bangsa-Bangsa."

Kovenan Internasional HakHak Ekonomi, Sosial Dan Budaya ${ }^{6}$ sebagaimana telah diratifikasi melalui Undang-Undang Republik Indonesia Nomor 11 Tahun 2005 Tentang Pengesahan International Covenant On Economic, Social And Cultural Rights (Kovenan Internasional Tentang Hak-Hak Ekonomi, Sosial Dan Budaya). Dengan batang tubuh sebagai berikut :

a. Prinsip-prinsip umum (Pasal 1).

b. Kewajiban umum negaranegara pihak (Pasal 2, 3, 4, 5).

c. Kewajiban negara-negara pihak untuk mengakui dan menjamin hak-hak asasi yang dimuat dalam kovenan (Pasal $6,7,8,9,10,11,12,13,14$, $15)$.

d. Ketentuan yang mengatur masalah pelaporan pelaksanaan instrument yang harus dilakukan oleh Negaranegara pihak serta tindak

${ }^{6}$ Ditetapkan oleh Resolusi Majelis Umum 2200 A (XXI) tertanggal 16 Desember 1966, dan terbuka untuk penandatangan, ratifikasi, dan aksesi. lanjut yang dapat dilakukan oleh Dewan Ekonomi dan Sosial (Pasal 16, 17, 18, 19, 20, 21, 22).

e. Ketentuan tentang berbagai bentuk aksi internasional bagi pencapaian hak-hak yang dimuat dalam kovenan (Pasal 23).

f. Penegasan bahwa ketentuanketentuan yang termaktub dalam instrumen tersebut tidak mengurangi tanggung jawab organ-organ PBB dan badan-badan khusus mengenai masalah-masalah yang disebut dalam kovenan sebagaimana yang ditetapkan oleh Piagam PBB serta akta konstitutif badan khusus masing-masing (Pasal 24).

g. Penegasan hak inheren semua rakyat untuk menikmati kekayaan dan sumber alamnya (Pasal 25).

h. Ketentuan Penutup yang mengatur masalah-masalah prosedural (Pasal 26, 27, 28, 29, 20, 31).

Kovenan ini mengatur beberapa hak yang berhubungan dengan bidang ekonomi, sosial dan budaya sebagaimana terdapat dalam tabel 1.

Kewajiban negara terhadap pemenuhan hak-hak ekonomi sosial dan budaya sebagaimana tercantum dalam Pasal 2 Setiap Negara Pihak pada Kovenan ini, berjanji untuk mengambil langkah-langkah, baik secara individual maupun melalui bantuan dan kerjasama internasional, khususnya dibidang ekonomi dan teknis sepanjang tersedia sumber dayanya, untuk secara progresif mencapai perwujudan penuh dari hak-hak yang diakui oleh kovenan ini dengan cara-cara yang sesuai, termasuk denagn pengambilan langkah-langkah legislatif. 
Negara Pihak menjamin bahwa hak-hak yang diatur dalam kovenan ini akan dilaksanakan tanpa diskriminasi apapun sepertii ras, warna kulit, jenis kelamin, bahasa, agama, politik atau pendapat lainnya, asal-usul kebangsaan atau sosial, kekayaan, kelahiran atau status lainnya.

Tabel 1

Hak-Hak Ekonomi, Sosial dan Budaya

\begin{tabular}{|c|c|c|c|}
\hline No. & Hak Ekonomi & Hak Sosial & Hak Budaya \\
\hline 1. & $\begin{array}{l}\text { Hak atas pekerjaan } \\
\text { a. hak atas upah yang layak } \\
\text { (Pasal 6). } \\
\text { b. hak untuk memilih } \\
\text { secara bebas atau } \\
\text { menerima suatu pekerjaan } \\
\text { (Pasal 6). }\end{array}$ & $\begin{array}{l}\text { Hak untuk mendapatkan } \\
\text { standar kehidupan yang } \\
\text { layak } \\
\text { a. hak atas standar } \\
\text { kehidupan yang layak (Pasal } \\
11 \text { ayat } 1 \text { ). } \\
\text { b. hak atas kecukupan } \\
\text { pangan (Pasal } 11 \text { ayat } 1 \text { ). } \\
\text { c. hak atas pemukiman } \\
\text { (Pasal } 11 \text { ayat } 1 \text { ). } \\
\text { d. hak untuk terbebas dari } \\
\text { kelaparan (Pasal } 11 \text { ayat } 2 \text { ). } \\
\text { e. hak atas jaminan sosial } \\
\text { (Pasal 9). }\end{array}$ & $\begin{array}{l}\text { Hak atas pendidikan } \\
\text { a. hak atas pendidikan } \\
\text { (Pasal 13). } \\
\text { b. hak untuk } \\
\text { mendapatkan wajib } \\
\text { belajar tingkat dasar } \\
\text { (Pasal 14). }\end{array}$ \\
\hline 2. & $\begin{array}{l}\text { Hak-hak buruh } \\
\text { a. hak untuk menikmati } \\
\text { kondisi kerja yang adil dan } \\
\text { baik (Pasal 7). } \\
\text { b. hak atas pemberian } \\
\text { upah yang layak untuk } \\
\text { hidup (Pasal 7a). } \\
\text { c. hak untuk membentuk } \\
\text { dan bergabung dengan } \\
\text { serikat pekerja } \\
\text { (Pasal 8). } \\
\text { d. hak untuk melakukan } \\
\text { pemogokan (Pasal } 8 \text { ayat } \\
\text { 1d). }\end{array}$ & $\begin{array}{l}\text { Hak atas keluarga, ibu dan } \\
\text { anak } \\
\text { a. hak atas keluarga, ibu dan } \\
\text { anak-anak (Pasal 10). } \\
\text { b. hak atas perlindungan } \\
\text { terhadap keluarga (Pasal 9). }\end{array}$ & $\begin{array}{l}\text { Hak atas kehidupan } \\
\text { budaya dan ilmu } \\
\text { pengetahuan } \\
\text { a. terhadap kemajuan } \\
\text { pengetahuan (Pasal } \\
\text { 15). } \\
\text { b. hak untuk menjadi } \\
\text { bagian dalam } \\
\text { kehidupan budaya } \\
\text { (Pasal 15). } \\
\text { c. hak atas kebebasan. }\end{array}$ \\
\hline 3. & & $\begin{array}{l}\text { Hak atas kesehatan fisik dan } \\
\text { mental (Pasal 12). }\end{array}$ & \\
\hline
\end{tabular}

Sedangkan bagi negara-negara berkembang, dengan memperhatikan hak asasi manusia dan perekonomian nasionalnya, dapat menentukan sampai seberapa jauh mereka dapat menjamin hak-hak ekonomi yang diakui dalam Kovenan ini kepada warga negara asing.

Kovenan Internasional Hak Sipil dan Hak Politik ${ }^{7}$ sebagaimana

\footnotetext{
${ }^{7}$ Ditetapkan oleh Resolusi Majelis Umum 2200 A (XXI) tertanggal 16 Desember 1966, dan terbuka untuk penandatangan, ratifikasi, dan aksesi.
}

telah diratifikasi melalui UndangUndang Republik Indonesia Nomor 12 Tahun 2005 Tentang Pengesahan International Covenant On Civil And Political Rights (Kovenan Internasional Tentang Hak-Hak Sipil Dan Politik). Tanggung jawab perlindungan dan pemenuhan atas semua hak dan kebebasan yang dijanjikan di dalam Kovenan ini adalah negara, khususnya yang menjadi negara Pihak ICCPR. Hal ini ditegaskan pada Pasal 2 (1) yang menyatakan, negara-negara Pihak 
diwajibkan untuk "menghormati dan menjamin hak-hak yang diakui dalam Kovenan ini, yang diperuntukkan bagi semua individu yang berada di dalam wilayah dan tunduk pada yurisdiksinya" tanpa diskriminasi macam apapun.

Hak dan kebebasan dalam kovenan ini sebagaimana tercantum dalam Pasal 2 (2) belum dijamin dalam yurisdiksi suatu negara, maka negara tersebut diharuskan untuk mengambil tindakan legislatif atau tindakan lainnya yang perlu guna mengefektifkan perlindungan hak-hak itu. Hubungan tanggung jawab negara dalam konteks memenuhi kewajiban yang muncul dari ICCPR ini, adalah bersifat mutlak dan harus segera dijalankan (immediately). Hak-hak yang terdapat dalam ICCPR ini bersifat justiciable. Hal ini yang membedakannya dengan tanggung jawab negara dalam konteks memenuhi kewajiban yang terbit dari ICESCR, yang tidak harus segera dijalankan pemenuhannya. Tetapi secara bertahap (progressive realization), dan karena itu bersifat non-justiciable.

Kewajiban negara yang lain yang tercantum dalam konvensi ini adalah kewajiban memberikan tindakan pemulihan bagi para korban pelanggaran hak atau kebebasan yang terdapat dalam kovenan ini secara efektif. Sistem hukum suatu negara diharuskan mempunyai perangkat yang efektif dalam menangani hakhak korban tersebut. Penegasan mengenai hal ini tertuang pada Pasal 3 , yang menyatakan sebagai berikut :

a. Menjamin bahwa setiap orang yang hak atau kebebasan sebagaimana diakui dalam Kovenan ini dilanggar, akan mendapat pemulihan yang efektif, meskipun pelanggaran itu dilakukan oleh orang yang bertindak dalam kapasitas resmi.

b. Menjamin bahwa bagi setiap orang yang menuntut pemulihan demikian, haknya atas pemulihan tersebut akan ditetapkan oleh lembaga peradilan, administrasi, atau legislatif yang berwenang, atau lembaga lain yang berwenang, yang ditentukan oleh system hukum negara tersebut, dan untuk mengembangkan kemungkinan pemulihan yang bersifat hukum.

c. Menjamin bahwa lembaga yang berwenang akan melaksanakan pemulihan tersebut apabila dikabulkan.

Klasifikasi terhadap hak-hak dan kebebasan dasar yang tercantum dalam ICCPR itu. Klasifikasi pertama adalah hak-hak dalam jenis nonderogable, yaitu hak-hak yang bersifat absolut yang tidak boleh dikurangi pemenuhannya oleh negara-negara pihak. Walaupun dalam keadaan darurat sekalipun. Hak-hak yang termasuk ke dalam jenis ini adalah :

(i) hak atas hidup (rights to life);

(ii) hak bebas dari penyiksaan (rights to be free from torture);

(iii) hak bebas dari perbudakan (rights to be free from slavery);

(iv) hak bebas dari penahanan karena gagal memenuhi perjanjian (utang);

(v) hak bebas dari pemidanaan yang berlaku surut;

(vi) hak sebagai subjek hukum; dan

(vii) hak atas kebebasan berpikir, keyakinan dan agama. Negaranegara Pihak yang melakukan pelanggaran terhadap hak-hak dalam jenis ini, seringkali akan mendapat kecaman sebagai Negara yang telah melakukan pelanggaran serius hak asasi manusia (gross violation of human rights).

Kelompok kedua adalah hakhak dalam jenis derogable, yakni hakhak yang boleh dikurangi atau dibatasi pemenuhannya oleh Negaranegara Pihak. Hak dan kebebasan yang termasuk dalam jenis ini adalah : (i) hak atas kebebasan berkumpul secara damai; 
(ii) hak atas kebebasan berserikat, termasuk membentuk dan menjadi anggota serikat buruh; dan

(iii) hak atas kebebasan menyatakan pendapat atau berekpresi, termasuk kebebasan mencari, menerima dan memberikan informasi dan segala macam gagasan tanpa memperhatikan batas (baik melalui lisan atau tulisan).

Konvensi Internasional Penghapusan Segala Bentuk Diskriminasi Rasial 1965 (International Convention on the Elimination of All Forms of Racial Discrimination 1965). ${ }^{8}$ Konvensi ini juga telah diratifikasi melalui Undangundang No.29 Tahun 1999 tentang Pengesahan International Convention On The Elimination Of All Forms Of Racial Discrimination 1965 (Konvensi Internasional Tentang Penghapusan segala Bentuk Diskriminasi Rasial 1965). Secara umum Bentuk diskriminasi ras dimaksud konvensi ini diartikan sebagai segala bentuk pembedaan, pengecualian, pembatasan, atau pengutamaan berdasarkan ras, warna kulit, keturunan atau kebangsaan atau sukubangsa, yang mempunyai maksud atau dampak meniadakan atau merusak pengakuan, pencapaian atau pelaksanaan, atas dasar persamaan, hak asasi manusia dan kebebasan dasar dalam bidang politik, ekonomi, sosial, budaya atau bidang kehidupan masyarakat yang lain. ${ }^{9}$

Tindakan khusus diambil untuk tujuan semata-mata menjamin kemajuan yang layak bagi kelompok

8 Diterima dan terbuka untuk pendatangangan dan pengesahan, Oleh Resolusi SMU Perserikatan Bangsa Bangsa no. 2106 (XX) 21 Desember 1965, Mulai berlaku sejak 4 Januari 1969

${ }^{9}$ Pasal 1 (1) International Convention on the Elimination of All Forms of Racial Discrimination 1965. ras atau sukubangsa atau perorangan tertentu yang memerlukan perlindungan, seperti yang diperlukan untuk menjamin adanya kesamaan dalam hal menikmati kemudahan atau menggunakan hak asasinya sebagai manusia dan kebebasan dasarnya, dan hal itu tidak dapat dianggap sebagai diskriminasi ras, asalkan tindakan seperti itu tidak berakibat munculnya perlakuan istimewa bagi kelompokkelompok ras yang berbeda, dan tindakan itu tidak dapat diteruskan setelah tujuan bagi mereka tercapai. ${ }^{10}$

Untuk memenuhi kewajibankewajiban dasar yang dicantumkan dalam Pasal 2 Konvensi ini, Negaranegara Pihak melarang dan menghapuskan segala bentuk diskriminasi ras serta menjamin hak setiap orang tanpa membedakan ras, warna kulit, asal bangsa dan sukubangsa, untuk diperlakukan sama di depan hukum, terutama untuk menikmati hak di bawah ini11:

(a) Hak untuk diperlakukan dengan sama di depan pengadilan dan badan-badan peradilan lain;

(b) Hak untuk rasa aman dan hak atas perlindungan oleh negara dari kekerasan dan kerusakan tubuh, baik yang dilakukan aparat pemerintah maupun suatu kelompok atau lembaga;

(c) Hak politik, khususnya hak ikut serta dalam pemilihan umum untuk memilih dan dipilih atas dasar hak pilih yang universal dan sama, ikut serta dalam pemerintahan maupun pelaksanaan masalah umum pada tingkat manapun, dan untuk memperoleh kesempatan yang sama atas pelayanan umum;

(d) Hak sipil lainnya, khususnya:

\footnotetext{
${ }^{10}$ Pasal 1 (3) International Convention on the Elimination of All Forms of Racial Discrimination 1965.

${ }^{11}$ Pasal 5 International Convention on the Elimination of All Forms of Racial Discrimination 1965.
} 
(i) Hak untuk bebas berpindah dan bertempat tinggal dalam wilayah negara yang bersangkutan;

(ii) Hak untuk meninggalkan suatu negara, termasuk negaranya sendiri, dan kembali ke negaranya sendiri;

(iii) Hak untuk memiliki kewarganegaraan;

(iv) Hak untuk menikah dan memilih teman hidup;

(v) Hak untuk memiliki kekayaan baik atas nama sendiri ataupun bersama dengan orang lain;

(vi) Hak waris;

(vii) Hak atas kebebasan berpikir, berkeyakinan, dan beragama;

(viii) Hak untuk berpendapat dan menyampaikan pendapat;

(ix) Hak berkumpul dan berserikat secara bebas dan damai;

(e) Hak ekonomi, sosial, dan budaya, khususnya:

(i) Hak untuk bekerja, memilih pekerjaan secara bebas, mendapatkan kondisi kerja yang adil dan nyaman, memperoleh perlindungan dari pengangguran, mendapat upah yang layak sesuai pekerjaannya, memperoleh gaji yang adil dan menguntungkan;

(ii) Hak untuk membentuk dan menjadi anggota serikat pekerja;

(iii) Hak atas perumahan;

(iv) Hak untuk mendapat pelayanan kesehatan, perawatan medis, jaminan sosial dan pelayananpelayanan sosial;

(v) Hak atas pendidikan dan pelatihan; (vi) Hak untuk berpartisipasi yang sama dalam kegiatan kebudayaan;

(vii) Hak untuk dapat memasuki suatu tempat atau pelayanan manapun yang dimaksudkan untuk digunakan masyarakat umum, seperti transportasi, hotel, restoran, warung kopi, teater, dan taman.

Pada dasarnya Konvensi Tentang Keanekaragaman Hayati 1992 (Convention On Biological Diversity 1992) telah diratifikasi kedalam hukum nasional Indonesia maka segala isi dari konvensi mengikat secara penuh dan menjadi bagian kaidah hukum nasional. Konvensi ini diratifikasi melalui Undang-undang No. 5 Tahun 1994 tentang Pengesahan Konvensi Internasional mengenai Keanekaragaman Hayati (United Nation Convention on Biological Diversity). Konvensi ini juga mengakui ketergantungan atau hubungan yang erat dan berciri tradisional sejumlah besar pada masyarakat lokal/setempat seperti tercermin dalam gaya hidup tradisional terhadap sumber daya hayati, dan keinginan untuk membagi keuntungan yang dihasilkan dari pemanfaatan pengetahuan, inovasiinovasi dan praktek-praktek tradisional yang berkaitan dengan konservasi keanekaragaman hayati dan pemanfaatan secara berkelanjutan komponenkomponennya secara adil.

Dalam Pasal 8 mengenai konservasi in-situ dalam huruf $\mathrm{j}$ dikatakan:... "menghormati, melindungi dan mempertahankan pengetahuan, inovasi-inovasi dan praktik-praktik masyarakat asli (masyarakat adat) dan lokal yang mencerminkan gaya hidup berciri tradisional, sesuai dengan konservasi dan pemanfaatan secara berkelanjutan keanekaragaman hayati 
dan memajukan penerapannya secara lebih luas dengan persetujuan dan keterlibatan pemilik pengetahuan, inovasi-inovasi dan praktek tersebut semacam itu dan mendorong pembagian yang adil keuntungan yang dihasilkan dari pendayagunaan pengetahuan, inovasi-inovasi dan praktek-praktek semacam itu.

Selanjutnya dalam Pasal 15 butir 4 dikatakan untuk mendapatkan akses atas sumber daya hayati bila diberikan, harus atas dasar persetujuan bersama (terutama pemilik atas sumber daya)."

Konvensi ILO 107 tentang Perlindungan dan Integrasi dari Penduduk Pribumi, Masyarakat Adat dan Masyarakat Semi-adat di Negaranegara Merdeka (Convention No.107 concerning Protection and Integration of Indigenous and other Tribal and Semi-Tribal Population in Independent Countries). ${ }^{12}$ Perlindungan dan penghormatan terhadap hak-hak masyarakat adat dalam Pasal 2 konvensi ini menyatakan bahwa:

"Governments shall have the primary responsibility for developing co-ordinated and systematic action for the protection of the populations concerned and their progressive integration into the life of their respective countries."

Pemerintah harus mengambil tanggung jawab penuh atau utama untuk mengembangkan dan tindakan tersistematis untuk perlindungan penduduk berkaitan dengan kemajuan terintegrasi kedalam kehidupan penghormatan terhadap masyarakat adat. Bentuk perlindungan lainnya adalah"13: "So long as the social, economic and cultural conditions of the populations concerned prevent them from enjoying

\footnotetext{
${ }^{12}$ Mulai Berlaku 02 Juni 1959, Adoption: Geneva, 40th ILC session (26 Jun 1957).

${ }^{13}$ Pasal 3 Konvensi ILO No. 107/1957.
}

the benefits of the general laws of the country to which they belong, special measures shall be adopted for the protection of the institutions, persons, property and labour of these populations."

Perlindungan masyarakat adat di bidang ekonomi, sosial dan budaya harus mereka nikmati keuntungan dari aturan hukum secara umum. Tindakan atau perlakuan secara khusus harus diberikan untuk perlindungan institusi, orang-orang, tempat tinggal dan buruh dalam populasi masyarakat adat. Sedangkan Pasal 6 menyatakan:

"The improvement of the conditions of life and work and level of education of the populations concerned shall be given high priority in plans for the over-all economic development of areas inhabited by these populations. Special projects for economic development of the areas in question shall also be so designed as to promote such improvement."

Perbaikan kondisi pada kehidupan masyarakat adat, pekerjaan dan tingkat pendidikan harus diberikan prioritas utama dalam pengembangan ekonomi masyarakat adat. Proyek khusus untuk pengembangan ekonomi wilayah harus desain sebagai promosi dan perbaikan terhadap masyarakat. Perlindungan penghormatan hak asasi manusia masyarakat adat terbatas pada pemenuhan bidang ekonomi, pendidikan, sosial dan budaya. Akan tetapi tidak membahas secara khusus mengenai perlindungan tanah adat serta bagaimana dan langkah-langkah dalam penyelesaian konflik.

Konvensi ILO 169 Tahun 1989 Mengenai Masyarakat Adat merupakan hasil revisi Konvensi ILO No. 107 Tahun 1957. Konvensi ini isinya terdiri dari 10 bagian dengan 
44 Pasal (ditambah Pembukaan). Bagian I (Pasal 1-12) berisi tentang penjelasan istilah, prinsip-prinsip, dan kewajiban negara. Bagian II (Pasal 1319) berisi tentang tanah, Bagian III (Pasal 20) berisi tentang penerimaan dan kondisi kerja buruh, Bagian IV (Pasal 21-23) berisi tentang pelatihan ketrampilan kerja, kerajinan tangan dan industri pedesaan, Bagian V (2425) berisi tentang jaminan sosial dan kesehatan, Bagian VI (Pasal 26-31) berisi tentang pendidikan dan sarana komunikasi, Bagian VII (Pasal 32) mengatur tentang hubungan dan kerjasama lintas perbatasan, Bagian VIII (Pasal 33) mengatur tentang administrasi, Bab IX (Pasal 34-35) mengatur tentang ketetapanketetapan umum, dan terakhir Bab X (Pasal 36-44) berisi tentang ketetapan-ketetapan akhir.

Konvensi ini memberikan defenisi sebagaimana yang dimaksud dengan masyarakat adat adalah "masyarakat yang berdiam di negaranegara merdeka dimana kondisi sosial, kultural dan ekonominya membedakan mereka dari bagianbagian masyarakat lain di negara tersebut dan statusnya diatur, baik seluruh maupun sebahagian oleh masyarakat adat dan tradisi masyarakat adat tersebut atau dengan hukum dan peraturan khusus". Masyarakat hukum adat di negaranegara merdeka yang dianggap sebagai pribumi karena mereka adalah keturunan dari penduduk yang mendiami negara yang bersangkutan, atau berdasarkan wilayah geografis tempat negara yang bersangkutan berada, pada waktu penaklukan atau penjajahan atau penetapan batasbatas negara saat ini dan yang, tanpa memandang status hukum mereka, tetap mempertahankan beberapa atau seluruh institusi sosial, ekonomi, budaya dan politik mereka sendiri. ${ }^{14}$

\footnotetext{
${ }^{14}$ Pasal 1 Konvensi ILO No. 169/1989.
}

Pemerintah mempunyai tanggung jawab untuk menyusun, dengan partisipasi dari masyarakat hukum adat yang bersangkutan, aksi yang terkoordinasi dan sistematis untuk melindungi hak-hak dari masyarakat hukum adat ini dan untuk menjamin dihormatinya keutuhan mereka. Aksi seperti itu meliputi langkah-langkah untuk ${ }^{15}$ :

a. memastikan bahwa para anggota dari masyarakat hukum adat ini mendapat manfaat berdasarkan kesetaraan derajat dari hak-hak dan kesempatan-kesempatan yang diberikan oleh undangundang dan peraturan-peraturan nasional kepada anggota-anggota lainnya dari penduduk negara tempat mereka tinggal;

b. mengupayakan terwujudnya secara penuh hak-hak sosial, ekonomi dan budaya dari masyarakat hukum adat ini dengan penghormatan terhadap identitas sosial dan budaya mereka, adat-istiadat dan tradisi mereka, serta institusi-institusi mereka;

c. membantu para anggota dari masyarakat hukum adat yang bersangkutan untuk menghapus kesenjangan sosial ekonomi yang dapat terjadi antara pribumi dan anggota-anggota lain masyarakat nasional, dengan cara yang sesuai dengan aspirasi dan cara hidup mereka.

Masyarakat hukum adat berhak menikmati hak-hak mereka sebagaimanusia dan kebebasankebebasan yang bersifat mendasar tanpa halangan atau diskriminasi. Ketentuan-ketentuan konvensi berlaku tanpa diskriminasi terhadap anggota laki-laki maupun anggota perempuan dari masyarakat hukum adat ini. Bentuk paksaan atau ancaman pemaksaan tidak boleh digunakan untuk melanggar hak-hak

\footnotetext{
${ }^{15}$ Pasal 2 Konvensi ILO No. 169/1989.
} 
sebagai manusia dan kebebasankebebasan yang bersifat mendasar dari masyarakat hukum adat yang bersangkutan, termasuk hak-hak yang terkandung dalam Konvensi ini. ${ }^{16}$

$$
\text { Upaya-upaya }
$$

khusus

ditetapkan sebagaimana semestinya untuk menjaga dan melindungi keselamatan warga, institusi, harta benda, tenaga kerja, budaya dan lingkungan hidup dari masyarakat hukum adat yang bersangkutan. Upaya-upaya khusus semacam itu tidak boleh bertentangan dengan harapan-harapan yang dengan bebas dinyatakan dari masyarakat hukum adat yang bersangkutan. Dinikmatinya hak-hak umum sebagai warga negara, tanpa diskriminasi, tidak boleh dikorbankan dengan cara apapun oleh upaya-upaya khusus semacam itu. ${ }^{17}$

Nilai-nilai dan praktik-praktik sosial, budaya, agama, dan spiritual (rohani) masyarakat hukum adat ini diakui dan dilindungi, dan hakikat dari masalah-masalah yang mereka hadapi baik sebagai kelompok maupun sebagai individu diperhatikan sebagaimana seharusnya. Keutuhan dari nilai-nilai, praktik-praktik dan institusi-institusi dari masyarakat hukum adat ini dihormati. Ditetapkan kebijakankebijakan yang ditujukan untuk mengurangi kesulitan-kesulitan yang dialami oleh masyarakat hukum adat ini dalam menghadapi kondisi-kondisi baru dalam kehidupan dan pekerjaan, dengan partisipasi dan kerja sama dari masyarakat hukum adat yang mengalami kondisi-kondisi baru tersebut. ${ }^{18}$

$$
\text { Dalam }
$$

menerapkan

ketentuan-ketentuan Konvensi ini, pemerintah $^{19}$ :

\footnotetext{
${ }^{16}$ Pasal 3 Konvensi ILO No. 169/1989.

${ }^{17}$ Pasal 4 Konvensi ILO No. 169/1989.

${ }^{18}$ Pasal 5 Konvensi ILO No. 169/1989.

${ }^{19}$ Pasal 6 Konvensi ILO No. 169/1989.
}

(a) mengkonsultasikannya dengan masyarakat hukum adat yang bersangkutan, melalui prosedurprosedur sebagaimana seharusnya dan terutama melalui institusi-institusi perwakilan mereka, setiap kali sedang dilakukan pertimbangan terhadap upaya-upaya legislatif atau administratif yang dapat langsung berpengaruh terhadap mereka;

(b) menetapkan cara-cara yang memungkinkan masyarakat hukum adat ini untuk dapat secara bebas berpartisipasi, sekurang-kurangnya pada tingkat yang sama seperti sektor-sektor lainnya dalam populasi, di seluruh tingkat pengambilan keputusan dalam institusiinstitusi pemilihan umum dan administrasi dan badan-badan lain yang bertanggung jawab atas kebijakan-kebijakan dan program-program yang menyangkut kepentingan mereka;

(c) menetapkan cara-cara untuk mengembangkan sepenuhnya institusi-institusi dan inisiatifinisiatif dari masyarakat hukum adat ini sendiri, dan dalam hal-hal yang semestinya, memberikan sumber-sumber daya yang perlu untuk maksud ini.

Konsultasi-konsultasi yang dilakukan dalam penerapan konvensi ini dilakukan dengan itikad baik dan dalam bentuk yang tepat dan sesuai dengan keadaan-keadaan yang ada, dengan tujuan agar upaya-upaya yang diusulkan mendapatkan kesepakatan atau izin.

Masyarakat hukum adat yang bersangkutan berhak memutuskan prioritas-prioritas mereka sendiri untuk proses pembangunan ketika proses tersebut mempengaruhi kehidupan, kepercayaan, institusiinstitusi dan kesejahteraan rohani mereka serta tanah-tanah yang mereka diami atau apabila tidak 
mereka diami, mereka gunakan, dan untuk menjalankan kendali, sedapat mungkin, terhadap pembangunan ekonomi, sosial dan budaya mereka sendiri. Di samping itu, mereka berpartisipasi dalam perumusan, implementasi dan evaluasi rencanarencana dan program-program pembangunan nasional maupun regional yang dapat membuat mereka secara langsung terkena dampaknya. Perbaikan kondisi-kondisi kehidupan dan pekerjaan serta tingkat-tingkat kesehatan dan pendidikan masyarakat hukum adat yang bersangkutan, dengan partisipasi dan kerja sama mereka, harus menjadi hal yang diprioritaskan dalam rencanarencana pembangunan ekonomi secara keseluruhan dari daerahdaerah yang mereka tinggali. Proyekproyek khusus bagi pembangunan daerah-daerah yang mereka tinggali itu juga harus dirancang sedemikian rupa guna mendorong terwujudnya perbaikan yang dimaksud. Pemerintah harus memastikan agar, bilamana selayaknya diperlukan, dilakukan studi, melalui kerja sama dengan masyarakat hukum adat yang bersangkutan, untuk menilai dampak sosial, rohani, budaya dan lingkungan hidup terhadap masyarakat hukum adat tersebut sebagai akibat dari kegiatan-kegiatan pembangunan yang direncanakan.

Pemerintahpemerintah harus mengambil upayaupaya, melalui kerja sama dengan masyarakat hukum adat yang bersangkutan, untuk melindungi dan melestarikan lingkungan hidup wilayah-wilayah yang mereka diami. ${ }^{20}$ Deklarasi Perserikatan Bangsa-Bangsa (PBB) Tentang HakHak Masyarakat Adat 2007 (United Nations Declaration on the Rights of Indigenous Peoples 2007- UNDRIP). ${ }^{21}$

\footnotetext{
${ }^{20}$ Pasal 7 Konvensi ILO No. 169/1989.

21 Disahkan dalam sidang umum PBB tanggal 13 September 2007 di New York,
}

Konvensi ini di bentuk dengan adanya kebutuhan yang mendesak untuk menghormati dan memajukan hakhak yang melekat pada masyarakat adat, yang berasal dari politik, ekonomi, struktur sosial dan budaya mereka, tradisi-tradisi keagamaan, sejarah-sejarah dan filsafat-filsafat mereka, khususnya hak-hak mereka atas tanah, wilayah dan sumber daya mereka, serta kontrol masyarakat adat terhadap pembangunan yang berdampak pada mereka dan tanahtanah mereka, wilayah dan sumber daya alam mereka, akan memungkinkan mereka untuk menjaga dan memperkuat lembagalembaga, budaya-budaya dan tradisitradisi mereka, dan untuk memajukan pembangunan mereka selaras dengan aspirasi-aspirasi dan kebutuhankebutuhan mereka. Dengan pemberian penghormatan terhadap pengetahuan, budaya dan praktekpraktek adat tradisional memberikan sumbangan bagi pembangunan berkelanjutan dan berkeadilan serta pengelolaan lingkungan secara tepat. Masyarakat adat mempunyai hak terhadap penikmatan penuh, untuk secara bersama-sama atau secara sendiri-sendiri, semua hak asasi manusia dan kebebasankebebasan dasar yang diakui dalam Piagam Perserikatan Bangsa-Bangsa, Deklarasi Universal Hak-Hak Asasi Manusia dan hukum internasional tentang hak asasi manusia. ${ }^{22}$ Masyarakat adat dan warga-warganya bebas dan sederajat dengan semua kelompok-kelompok masyarakat dan warga-warga lainnya, dan mempunyai hak untuk bebas dari segala bentuk diskriminasi dalam menjalankan hakhak mereka, khususnya yang

Indonesia Adalah salah satu Negara yang menyatakan mendukung Deklarasi ini.

${ }^{22}$ Pasal 1 Deklarasi Perserikatan Bangsa-

Bangsa (PBB) Tentang Hak-Hak Masyarakat Adat (HMA) 2007. 
didasarkan atas asal-usul atau identitas mereka. ${ }^{23}$

Masyarakat adat mempunyai hak untuk menentukan nasib sendiri. Berdasarkan hak tersebut, mereka secara bebas menentukan status politik mereka dan secara bebas mengembangkan kemajuan ekonomi, sosial dan budaya mereka.24 Dalam melaksanakan hak mereka untuk menentukan nasib sendiri, memiliki hak otonomi atau pemerintahan sendiri dalam masalah-masalah yang berkaitan dengan urusan-urusan internal dan lokal mereka, juga caracara dan sarana-sarana untuk mendanai fungsi-fungsi otonomi mereka. ${ }^{25}$ Masyarakat Adat mempunyai hak untuk menjaga dan memperkuat ciri-ciri mereka yang berbeda di bidang politik, hukum, ekonomi, sosial dan institusi-institusi budaya, seraya tetap mempertahankan hak mereka untuk berpartisipasi secara penuh, jika mereka menghendaki, dalam kehidupan politik, ekonomi, sosial dan budaya Negara. ${ }^{26}$

Masyarakat adat tidak boleh dipindahkan secara paksa dari tanah atau wilayah mereka. Tidak boleh ada relokasi yang terjadi tanpa persetujuan bebas dan sadar, tanpa paksaan dari masyarakat adat yang bersangkutan, dan hanya boleh setelah ada kesepakatan perihal ganti kerugian yang adil dan memuaskan, dan jika memungkinkan, dengan pilihan untuk kembali lagi. ${ }^{27}$ Masyarakat adat mempunyai hak untuk mempraktikkan dan memperbarui tradisi-tradisi dan adat budaya mereka. Hal ini meliputi hak untuk mempertahankan, melindungi dan mengembangkan wujud kebudayaan mereka di masa lalu,

\footnotetext{
${ }^{23}$ Pasal 2 Deklarasi HMA PBB

${ }^{24}$ Pasal 3 Deklarasi HMA PBB

${ }^{25}$ Pasal 4 Deklarasi HMA PBB

${ }^{26}$ Pasal 5 Deklarasi HMA PBB

${ }^{27}$ Pasal 10 Deklarasi HMA PBB
}

sekarang dan yang akan datang, seperti situs-situs arkeologi dan sejarah, artefak, disain, upacarauparaca, teknologi, seni visual dan seni pertunjukan dan kesusasteraan. Negara-negara akan melakukan pemulihan melalui mekanisme yang efektif termasuk restitusi, yang dibangun dalam hubungannya dengan masyarakat adat, dengan rasa hormat pada kekayaan budaya, intelektual, religi dan spiritual mereka, yang telah diambil tanpa persetujuan bebas dan sadar dari mereka, atau yang melanggar hukum-hukum, tradisi dan adat mereka. ${ }^{28}$

Masyarakat adat mempunyai hak untuk berpartisipasi dalam proses pembuatan keputusan berkenaan dengan hal-hal yang akan membawa dampak pada hak-hak mereka, melalui perwakilanperwakilan yang mereka pilih sesuai dengan prosedur mereka sendiri, dan juga untuk mempertahankan dan mengembangkan pranata pembuatan keputusan yang mereka miliki secara tradisional. ${ }^{29} \quad$ Negara mengkonsultasikan dan bekerjasama secara tulus dengan masyarakat adat melalui institusi-institusi perwakilan mereka sendiri agar mereka bisa secara bebas menentukan persetujuan mereka sebelum menerima dan melaksanakan undangundang atau tindakan administratif yang mungkin mempengaruhi mereka. ${ }^{30}$

Masyarakat adat memiliki hak atas tanah-tanah, wilayah-wilayah dan sumber daya-sumber daya yang mereka miliki atau duduki secara tradisional atau sebaliknya tanahtanah, wilayah-wilayah dan sumber daya-sumber daya yang telah digunakan atau yang telah didapatkan. Masyarakat adat memiliki hak untuk memiliki, menggunakan,

\footnotetext{
${ }^{28}$ Pasal 11 (1 \& 2) Deklarasi HMA PBB

${ }^{29}$ Pasal 18 Deklarasi HMA PBB

${ }^{30}$ Pasal 19 Deklarasi HMA PBB
} 
mengembangkan dan mengontrol tanah-tanah, wilayah-wilayah dan sumber daya-sumber daya yang mereka miliki atas dasar kepemilikan tradisional atau penempatan dan pemanfaatan secara tradisional lainnya, juga tanah-tanah, wilayahwilayah dan sumber daya yang dimiliki dengan cara lain. Negaranegara akan memberikan pengakuan hukum dan perlindungan atas tanahtanah, wilayah-wilayah dan sumber daya-sumber daya tersebut. Pengakuan itu harus dilakukan sejalan dengan penghormatan atas kebiasaan-kebiasaan, tradisi-tradisi dan sistem penguasaan tanah pada masyarakat adat yang bersangkutan. ${ }^{31}$ Negara diwajibkan

membentuk dan

mengimplementasikan, dalam hubungannya dengan masyarakat adat yang bersangkutan, sebuah proses yang adil, independen, tidak memihak, terbuka dan transparan, dalam memberikan pengakuan yang benar atas hukum-hukum masyarakat adat, tradisi-tradisi, kebiasaankebiasaan dan sistem-sistem penguasaan tanah, untuk mengakui dan memutuskan hak-hak masyarakat adat atas tanah, wilayah dan sumber daya mereka yang lainnya, termasuk yang dimiliki secara tradisional atau sebaliknya dikuasai atau digunakan. Masyarakat adat memiliki hak untuk berpartisipasi dalam proses-proses ini. ${ }^{32}$ Masyarakat adat memiliki hak untuk mendapatkan ganti kerugian, dengan cara-cara termasuk restitusi atau, jika ini tidak memungkinkan, kompensasi yang layak dan adil, atas tanah, wilayah dan sumber daya yang mereka miliki secara tradisional atau sebaliknya tanah, wilayah dan sumber daya yang dikuasai atau digunakan, dan yang telah disita, diambil alih, dikuasai, digunakan atau dirusak tanpa persetujuan bebas tanpa

\footnotetext{
${ }^{31}$ Pasal $26(1,2, \&$ 3) Deklarasi HMA PBB

${ }^{32}$ Pasal 27 Deklarasi HMA PBB
}

paksaan dari mereka terlebih dahulu kecuali melalui persetujuan yang dilakukan secara bebas oleh kelompok masyarakat yang bersangkutan, kompensasi atas tanah, wilayah dan sumber daya akan dilakukan berdasarkan pertimbangan terhadap kualitas, ukuran dan status hukum atau berdasarkan kompensasi moneter atau ganti rugi yang layak lainnya. ${ }^{33}$

Masyarakat adat mempunyai hak atas pemulihan dan perlindungan lingkungan hidup dan kapasitas produktif tanah, wilayah dan sumber daya-sumber daya alam mereka. Negara juga membentuk dan menjalankan program-program bantuan untuk masyarakat adat seperti konservasi dan perlindungan, tanpa diskriminasi. Negara diberikan kewenangan untuk mengambil langkah-langkah yang efektif untuk memastikan bahwa tidak ada penyimpangan atau pembuangan bahan-bahan berbahaya di atas tanahtanah dan wilayah-wilayah masyarakat adat tanpa persetujuan bebas dan sadar tanpa paksaan dari mereka. Selanjutnya negara akan mengambil langkah-langkah efektif untuk memastikan, manakala diperlukan, bahwa program-program pemantauan, mempertahankan dan pemulihan kesehatan masyarakat adat, sebagaimana telah dikembangkan dan dilaksanakan oleh masyarakat adat yang terkena dampak dari bahan-bahan seperti itu, benar-benar dilaksanakan. ${ }^{34}$ Aktifitasaktifitas militer tidak boleh dilakukan di tanah atau wilayah masyarakat adat, kecuali dibenarkan oleh sebuah keadaan yang mengancam kepentingan umum atau dapat juga dilakukan berdasarkan persetujuan secara bebas dengan atau karena

\footnotetext{
${ }^{33}$ Pasal 28 (1 \& 2) Deklarasi HMA PBB

${ }^{34}$ Pasal 29 (1, 2 \& 3) Deklarasi HMA PBB
} 
diminta oleh masyarakat adat yang bersangkutan. ${ }^{35}$

Masyarakat adat memiliki hak untuk menentukan dan mengembangkan prioritas-prioritas dan strategi-strategi untuk pembangunan atau penggunaan tanah-tanah atau wilayah mereka dan sumber daya lainnya. Selanjutnya negara akan melakukan perundingan dan bekerjasama dalam cara-cara yang tulus dengan masyarakat adat melalui institusi-institusi perwakilan mereka sendiri supaya mereka dapat mencapai persetujuan yang bebas tanpa paksaan sebelum menyetujui proyek apapun yang berpengaruh atas tanah-tanah atau wilayah mereka dan sumber daya yang lainnya, terutama yang berhubungan dengan pembangunan, pemanfaatan atau eksploitasi atas mineral, air, dan sumber daya mereka yang lainnya. Negara harus menyediakan mekanisme yang efektif untuk ganti rugi yang adil dan pantas untuk aktifitas apapun, dan langkah-langkah yang tepat akan diambil untuk mengurangi pengaruh kerusakan lingkungan hidup, ekonomi, sosial dan budaya atau spiritual. ${ }^{36}$

Masyarakat adat memiliki hak atas akses ke, dan untuk memperoleh keputusan secara cepat melalui prosedur-prosedur yang adil dan disetujui secara bersama bagi, penyelesaian konflik dan sengketa dengan Negara dan pihak-pihak yang lain, dan juga bagi pemulihan yang efektif untuk semua pelanggaran hakhak individual dan kolektif mereka. Keputusan seperti itu harus mempertimbangkan adat, tradisi, peraturan-peraturan dan sistem hukum dari masyarakat adat yang bersangkutan dan hak asasi manusia internasional. ${ }^{37}$

\footnotetext{
${ }^{35}$ Pasal 30 (1) Deklarasi HMA PBB

${ }^{36}$ Pasal 32 (1, 2, \& 3) Deklarasi HMA PBB

${ }^{37}$ Pasal 40 Deklarasi HMA PBB
}

\section{PENUTUP}

A. Kesimpulan

Berdasarkan uraian pada babbab sebelumnya yang merupakan analisis terdahadp identifikasi masalah, teori-teori, aturan hukum internasional yang terkait, dan hasil penelitian, maka kesimpulan dalam penelitian ini adalah Pengaturan hukum internasional yang berhubungan dengan perlindungan hukum hak-hak masyarakat adat berdasarkan perjanjian internasional dimulai dengan Deklarasi Universal Hak Asasi Manusia 1948 (Universal Declaration of Human Rights-UDHR) 1948 yang mencantumkan nilai-nilai hak-hak dasar bagi seluruh umat manusia di dunia, selanjutnya Kovenan Internasional Hak-Hak Ekonomi, Sosial Dan Budaya 1966 (International Covenant on Economic, Social and Cultural Rights 1966) dan Kovenan Internasional Hak-Hak Sipil dan Politik 1966 (International Covenant on Civil and Political Rights 1966), Konvensi Internasional Penghapusan Segala Bentuk Diskriminasi Rasial 1965 (International Convention on the Elimination of All Forms of Racial Discrimination 1965), Konvensi Tentang Keanekaragaman Hayati 1992 (Convention On Biological Diversity 1992), Konvensi ILO No. 107 Tahun 1957 tentang Perlindungan dan Integrasi dari Penduduk Pribumi, Masyarakat Adat dan Masyarakat Semi-adat di Negara-negara Merdeka (Convention No.107 concerning Protection and Integration of Indigenous and other Tribal and SemiTribal Population in Independent Countries), Konvensi ILO No. 169 Tahun 1989 mengenai Bangsa Pribumi dan Masyarakat Adat di Negara-negara Merdeka (Convention No. 169 concerning Indigenous and Tribal Peoples in Independent Countries). Deklarasi Perserikatan Bangsa-Bangsa (PBB) Tentang HakHak Masyarakat Adat 2007 United 
Nations Declaration on the Rights of Indegenous Peoples 2007 berdasarkan Resolusi Majelis Umum PBB A/61/L.67, 7 September 2007 yang disahkan dalam sidang umum PBB tanggal 13 September 2007 di New York. Terdapat empat perjanjian internasional yang telah diratifikasi oleh Indonesia yaitu : Kovenan Internasional Hak-Hak Ekonomi, Sosial Dan Budaya 1966, Kovenan Internasional Hak-Hak Sipil dan Politik 1966, Konvensi Internasional Penghapusan Segala Bentuk Diskriminasi Rasial 1965, dan Konvensi Tentang Keanekaragaman Hayati 1992 (Convention On Biological Diversity 1992). Maka sejak perjanjian internasional ini diratifikasi maka secara yuridis telah menjadi bagian kedalam hukum nasional dan Indonesia melalui pemerintah mempunyai kewajiban untuk memenuhi memberikan perlindungan dan penghormatan terhadap hak-hak masyarakat adat yang diakui sebagaimana tercantum dalam perjanjian internasional yang diratifikasi.

\section{Daftar Pustaka}

\section{A. Buku}

A. Masyhur Effendi, Perkembangan Dimensi Hak Asasi Manusia \& Proses Dinamika Penyusunan Hukum Hak Asasi Manusia, Ghalia Indonesia, Bogor, 2005.

A. Mukthie Fadjar, Tipe Negara Hukum, Bayu Media, Jawa Timur, 2005.

Abdullah Yazid, et.al, Demokrasi dan Hak Asasi Manusia, Averroes Press, Malang, 2007.

Bernard Arief Sidharta, Refleksi Tentang Struktur Ilmu Hukum (Sebuah Penelitian Tentang Fundasi Kefilsafatan Dan Sifat Keilmuan Ilmu Hukum Sebagai Landasan Pengembangan Ilmu Hukum Nasional Indonesia), Mandar Maju, 2000.
Budiono Kusumohamidjojo, Suatu Studi Terhadap Aspek Operasional Konvensi Wina Tahun 1969 tentang Hukum Perjanjian Internasional, Binacipta, Bandung, 1986.

G. J. H. Van Hoof, Rethinking the Sources of International Law, IJsselstein, Netherlands, 1983.

Georg Schwarzengerber, International Law, Volume I (International Law as Applied by International Courts and Tribunals:I, $3^{\text {rd }}$ ed, Stevens \& Sons Ltd, London, 1957.

Hikmahanto Juwana, Bunga Rampai : Hukum Internasional dan Hukum Ekonomi, Lentera Hati, Jakarta, 2002.

Huala Adolf, Aspek-Aspek Negara Dalam Hukum Internasional, RajaGrafindo Persada, Jakarta, 2002.

Ian Brownlie (Penyunting), DokumenDokumen Pokok Mengenai Hak Asasi Manusia, edisi ke-2, Beriansyah (Penerjemah), UIPress, 1993.

Ian Brownlie, Principle of Public International Law, 5th ed. Clarendon Press, Oxford. 1998.

Ifdhal Kasim \& Johanes da Masenus Arus (Ed), Hak Ekonomi, Sosial, Budaya, (Esai-Esai Pilihan), Buku 2, Elsam, Jakarta, 2001.

J. L. Brierly, the Law of Nations (an Introduction to the International Law of Peace), 5th ed, Clarendon Press, London, 1955.

James W. Nickel, Hak Asasi Manusia (Refleksi Filosofis atas Deklarasi Universal Hak Asasi Manusia), Titis Eddy Ariani (Penerjemah), Gramedia Pustaka Umum, Jakarta, 1996.

Jayantha Perera, Land and Cultural Survival (The Communal Land Rights of Indigenous Peoples in Asia), ADB, 2009. 
LG. Saraswati, et. al. Hak Asasi Manusia (Teori, Hukum, Kasus), Rocky Gerung (ed), Filsafat UI-Press, Depok, 2006.

M. Sabir, Politik Bebas Aktif (Tantangan dan Kesempatan), CV. Haji Masagung, Jakarta, 1987.

Mochtar Kusumaatmadja, Pengantar hukum Internasional, Buku I (bagian Umum), Cetakan Ketiga, Binacipta, Bandung, 1981.

Mochtar Kusumaatmadja \& Etty R. Agoes, Pengantar Hukum Internasional, Alumni, Bandung, 2003.

Muladi (Editor), Hak Asasi Manusia (Hakekat, Konsep Dan Implikasinya Dalam Perspektif Hukum dan masyarakat), Refika Aditama, Bandung, 2005.

Rafael Edi Bosko, Hak-Hak Masyarakat Adat (Dalam Konteks Pengelolaan Sumber Daya Alam), ELSAM, 2006.

Rikardo Simarmata, Pengakuan Hukum terhadap Masyarakat Adat di Indonesia, UNDP, Jakarta, 2006.

Rukmana Amanwinata, Pengaturan dan Batas Implementasi Kemerdekaan Berserikat dan Berkumpul dalam Pasal 28 UUD 1945, Disertasi, Universitas Padjadjaran, Bandung, 1996.

Sarah Joseph, et.al, the International Covenant on Civil and Political Rights (Cases, Materials and Commentary), 2nd ed, Oxford University Press, 2004.

Scott Davidson, Hak Asasi Manusia (Sejarah, Teori, dan Praktek dalam Pergaulan Internasional), A. Hadyana Pudjaatka (Penerjemah), Pustaka Utama Grafiti, Jakarta, 1994.
Theo Huijbers, Filsafat Hukum, Cetakan ketiga, Yayasan Kanisius, Yogyakarta, $1995 .$.

Yudha Bhakti Ardhiwisastra, Hukum Internasional (Bunga Rampai), Alumni, Bandung, 2003.

Yudha Bhakti Ardhiwisastra, Imunitas Kedaulatan Negara Di Forum Pengadilan Asing, Penerbit PT. Alumni, Bandung, 1999.

\section{B. Jurnal, Artikel, Makalah,} Internet \& Sumber Lainnya.

Hak-Hak Masyarakat adat dan Pengurangan Emisi dari Pengurangan Deforestasi dan Degradasi Hutan: Perkara Masyarakat Saramaka melawan Suriname, Forest Peoples Programme, 2009. Lihat dalam http://www.forestpeoples.org /.../surinamesaramakaandred djudgmentmar09ind.pdf, diakses pada tanggal 2 Pebruari 2011.

Inisiatif \& Kebijakan yang Berhubungan dengan Hak-Hak Masyarakat Adat, Kumpulan Diskusi \& Presentasi,Kedai (Kelompok Diskusi Adat Indonesia)- International Centre For Research In Agroforestry, 2000. Lihat dalam http:// www.worldagroforestrycentre .org/sea/Publications/.../BK0 021-04.PDF. diakses pada 10 Pebruari 2011.

Mirza Nasution, "Tinjauan Konstitusional Terhadap Pelaksanaan Pemilu Dalam Negara Demokrasi Indonesia," USU Digital Library, 2004, hlm. 1. Dapat dilihat dalam situs http://www.library.usu.ac.id/ download/fh/tatanegaramirza2.pdf/. Di akses 22 Juni 2008.

R. Herlambang Perdana Wiratraman, Konstitusionalisme \& Hak-Hak Asasi Manusia (Konsepsi Tanggung Jawab Negara 
Dalam Sistem Ketatanegaraan Indonesia), Jurnal Ilmu Hukum Yuridika Vol. 20, No. I, Januari 2005. Hlm. 2.

Tom Griffiths, Indigenous Peoples, Human Rights and Development Agency Standards: a comparative review, A Forest Peoples Programme Briefing Paper, UK, 2003.

\section{B. Dokumen}

Deklarasi Universal Hak Asasi Manusia 1948 (Universal Declaration of Human RightsUDHR) 1948.

Kovenan Internasional Hak-Hak Ekonomi, Sosial Dan Budaya 1966 International Covenant on Economic, Social and Cultural Rights 1966).

Kovenan Internasional Hak-Hak Sipil dan Politik 1966 (International Covenant on Civil and Political Rights 1966).

Konvensi Internasional Penghapusan Segala Bentuk Diskriminasi Rasial 1965 (International Convention on the Elimination of All Forms of Racial Discrimination 1965).

Konvensi Tentang Keanekaragaman Hayati 1992 (Convention On Biological Diversity 1992).

Konvensi ILO No. 107 Tahun 1957 tentang Perlindungan dan Integrasi dari Penduduk Pribumi, Masyarakat Adat dan Masyarakat Semi-adat di Negara-negara Merdeka (Convention No.107 concerning Protection and Integration of Indigenous and other Tribal and Semi-Tribal Population in Independent Countries).

Konvensi ILO No. 169 Tahun 1989 mengenai Bangsa Pribumi dan Masyarakat Adat di Negaranegara Merdeka (Convention No. 169 concerning Indigenous

\author{
and Tribal Peoples in \\ Independent Countries).
}

Deklarasi Perserikatan BangsaBangsa (PBB) Tentang HakHak Masyarakat Adat 2007 United Nations Declaration on the Rights of Indegenous Peoples 2007 berdasarkan Resolusi Majelis Umum PBB A/61/L.67, 7 September 2007. Disahkan dalam sidang umum PBB tanggal 13 September 2007 di New York. 